\title{
Chikungunya - A Persistent Pakistani Public Health Crisis
}

\author{
Amna Amad Siddiqui*, Meeshal Khan and Syeda Kanza Kazmi \\ Dow University of Health Sciences, Pakistan
}

Submission: October 01, 2018; Published: October 12, 2018

*Corresponding author: Amna Amad Siddiqui, Dow University of Health Sciences,Baba-e-Urdu Road Karachi,Postal Code: 74200, Pakistan, Email: amna.sid@hotmail.com

\section{Letter to Editor}

Over the past few years, Pakistan has been under a significant burden of various health crises--ranging from our persistent battle with the polio virus to a boom in infectious outbreaks such as that of Dengue Fever and Crimean Congo Haemorrhagic Fever. Despite multiple such challenges over the decade, presence of an ongoing Chikungunya epidemic in Pakistan makes the inefficiency of our public health system glaringly obvious.

A viral disease transmitted by mosquitoes (Aedes aegypti and Aedes albopictus), Chikungunya was first isolated in Pakistan in rodents and one human by Darvesh et al.[1]. Later, it was detected in a number of individuals in Lahore amidst the dengue epidemic of 2011 [2]. Since the official report of an outbreak in November 2016, [3] cases of chikungunya have had an exponential increase with 405 reported cases in 2016 and a total of 4,868 cases in 2017, with majority (4138) reported from Karachi while the rest from Tharparkar and other districts of Sindh [4]. Although with a low mortality risk, infection with the chikungunya virus can be chronic with systemic complications and can, in rare case, prove to be fatal. Symptoms of this condition mainly include fever and joint pain. Patients may also present with muscle pain, headache, rash, nausea and fatigue. Joint pain in particular can be debilitating and may last for years [5].

Several factors have contributed to the difficulty in battling this major public health concern; deplorable sanitary conditions of the affected areas with widespread decomposing waste, open feculent sewers and gutters, inappropriate disposal of garbage and most importantly insufficient reduction in exposed waterfilled containers and stagnant water bodies have made our communities an excellent breeding ground for mosquitos that serve as a vector for chikungunya, among other transmissible diseases (the most notable of which in our set-up is Dengue Fever). A consistent failure of the government authorities to note and rectify this predicament serves as a major obstacle in solving this ongoing epidemic.
Furthermore, abrupt climate changes in Pakistan with harsher summers and milder winters with each passing year can also be correlated with an explosive rise in vector-borne diseases [6]. Poor government-led healthcare facilities, lack of public education, and an altogether absence of systematic strategies to battle this outbreak from a nationwide epidemic perspective has led this outbreak to flourish instead of diminishing since its inception in 2016. Besides spraying drives across affected areas to eradicate mosquitoes, [7] there has been no effort to eliminate unhygienic mounds of garbage and waste all over the cities for vector control. Public awareness and education about prevention and control techniques, improvement in public healthcare infrastructure, surveillance of further spread of the virus and promotion of research to combat this disease are some modalities that the healthcare authorities must put emphasize on in order to provide adequate protection to the general masses against this disease outbreak.

\section{References}

1. Darwish MA, Hoogstraal H, Roberts TJ, Ahmed IP, Omar F (1983) A sero-epidemiological survey for certain arboviruses (Togaviridae) in Pakistan. Trans R Soc Trop Med Hyg 77(4): 442-445.

2. Afzal MF, Naqvi SQ Sultan MA, Hanif A (2015) Chikungunya fever among children presenting with nonspecific febrile illness during an epidemic of dengue fever in Lahore, Pakistan. Merit Res J Med Medical Sci 3(3): 69-73.

3. Shehrish Wasif The Express Tribune, Pakistan officially reports Chikungunya outbreak to WHO.

4. PPI. Pakistan Today, 10 more chikungunya cases reported in Karachi.

5. WHO, Factsheet, Chikungunya.

6. WHO, Pakistan. Climate change and health.

7. Mallhi TH, Khan YH, Khan AH, Tanveer N, Qadir MI (2017) First chikungunya outbreak in Pakistan: a trail of viral attacks. New Microbes New Infect 19: 13-14. 
This work is licensed under Creative Commons Attribution 4.0 License

DOI: 10.19080/JOJCS.2018.08.555750
Your next submission with Juniper Publishers will reach you the below assets

- Quality Editorial service

- Swift Peer Review

- Reprints availability

- E-prints Service

- Manuscript Podcast for convenient understanding

- Global attainment for your research

- Manuscript accessibility in different formats

( Pdf, E-pub, Full Text, Audio)

- Unceasing customer service

Track the below URL for one-step submission https://juniperpublishers.com/online-submission.php 